\title{
Discussion on the Training Mode of Business English Major
}

\author{
Lu Sun ${ }^{1, a^{*}}$ \\ ${ }^{1}$ Harbin University of Commerce, Harbin, China, 150028 \\ aSUN LU1980@163.com
}

The corresponding author

\begin{abstract}
Keywords: Training mode; Business English; Information
\end{abstract}
\begin{abstract}
This paper discusses two key points in cultivating the talents of compound Business English, one is to strengthen the construction of business English courses, and the other is to improve the level of foreign language teachers. Through an overview of our professional college business English curriculum, the curriculum, teaching, deconstruction and three leading sectors are analyzed, and based on the characteristics of college foreign language education aims to cultivate talents, training mode on the construction of business English discipline, provide a useful reference to the discipline construction of China's College of business English.
\end{abstract}

\section{Introduction}

Business English is a kind of Purpose (English for Specific, ESP), which is the inevitable product of economic globalization. Its subject characteristics are influenced by linguistics and some other subjects. It can be said that it is a comprehensive subject, which is based on linguistics and absorbs other research methods. Business English talents not only have outstanding skills in English major, but also have a good knowledge of business activities. The business English major has become a new field of study.

\section{Strengthening the Construction of Business English Courses}

Curriculum is the basic unit of teaching. The scientific nature of curriculum system and the advancement of teaching content are directly related to the development of curriculum construction. The construction and development of the course can be divided into the construction of the curriculum system and the reform of the teaching content, the use of teaching methods and means, the establishment of the test model, the practice teaching of the experiment and practice, etc.. In order to make the development of curriculum construction work, from the school, should optimize the curriculum system, the rational allocation of the credit and the number of hours, contradictions, change course and basic course of interaction between compulsory course and elective course proportion; from the students' comprehensive quality and ability training of the rational proportion of related knowledge among the various disciplines. Pay attention to the integrity and systematization of each course content, but also make great efforts to solve the problem of repetition. The teaching contents to update and improve the requirements of teachers in the premise of correctly handling the classic content and modern content, the latest achievements and relevant theories, and the latest development into the curriculum, teaching content and follow the pace of development beyond the existing teaching content; the integration of course content. Renovation, reasonable specification and integration of curriculum content on the whole.

Through the study of business English courses, students should develop into a new type of foreign language talents who are proficient in English and have a systematic grasp of business technology. The situation and the creation of business English from the current school curriculum, can be divided into two major courses, one is the business background of English reading, writing and translating, listening and speaking course, such as: International Finance, International Business English English, business English, international trade English reading, English business letters, business English translation, business English communication and so on. Two is the main course, 
the professional direction of international trade such as: investment, international finance, international commercial law, international trade practice, international marketing, negotiation and communication, marketing, economics, business, marketing and public relations skills, human resources management and practice etc. These courses to ensure that the students through the systematic study of English skills and business skills to meet the requirements of a complex talent. From the current school training program can be seen, each of the training objectives, business English in the whole process of training, the proportion can be differentiated, teaching content can also be increased by. Train students to develop in three directions, one is to understand English business talents, and the other is to understand the business English talents, the three is not only understand the business and understand English talents.

\section{Business English Teaching}

The Use of Teaching Methods and Means. Business English is to cultivate the applied talents, more requirements are more. [4] traditional "indoctrination" teaching method is a single teaching to the students, can not teach students how to learn independently. The reform of "single classroom teaching", and actively carry out the "interaction" in various forms, to improve the initiative of students, learning at the same time, according to the characteristics of the course, make full use of modern educational technology and teaching means. Take the interview, communication, reporting and other forms of training teachers to actively participate in the teaching reform, devote classroom teaching activities, establish teaching consciousness, self-examination, self consciousness into good; encourage teachers to participate in the multimedia classroom teaching, network teaching, fully tap the modern educational technology theory and methods of resources, provide a good test site for foreign language teaching, in order to improve the efficiency of foreign language teaching and the cultivation of qualified foreign language talents accumulation of mature experience.

The Establishment of Examination Mode. The curriculum development should be based on students' knowledge, ability and quality comprehensive assessment as the goal, according to the different nature and characteristics of the course, take the examination method of diversification, and actively carry out the reform of the examination content; to cultivate the thinking ability and innovation principle, establish a scientific and reasonable evaluation system, better play the incentive function of examination and education the feedback control function, so as to guide the students' autonomous learning, improve their comprehensive ability to use knowledge.

Attach Importance to Practice Teaching. Practice teaching is to improve students' comprehensive quality and cultivate students' innovative spirit and practical ability, so that any theory teaching practice teaching has an irreplaceable role, is an important guarantee to complete the task of teaching, and students to an important warm-up before work. Therefore, we should attach great importance to the practical teaching of experiment and practice. To mobilize social forces, strengthen the construction of practice base, to vigorously carry out the reform and practice of teaching content and teaching method, teaching design, comprehensive research, experiment, guide and encourage students to participate in scientific research activities, carrying out research-based teaching, improve students' practical ability, innovation ability and entrepreneurial ability. Only in this way can we develop the business English talents to meet the needs of the society.

\section{Improve the Level of Business English Teachers}

Although the establishment of business English is short, the development of this discipline is the inevitable outcome of the development of economic globalization. How to promote the development of the discipline system of business English is the need for every business English teaching workers to continue to think, but also need to learn from other disciplines, research methods and means for scientific research.

Strengthen the Construction of Teachers. The teacher is the main body of the teaching process, the primary task of discipline construction is to strengthen the construction of teaching staff. By 
strengthening the construction of teaching staff, and gradually forming a reasonable structure, stable personnel, high teaching level, good teaching effect of the teaching team, can effectively ensure the quality of the compound talents training. English teachers are usually composed of three parts: full-time teachers, foreign teachers, or part-time teachers. Teachers should have modern educational thoughts and the educational concept of people-oriented, dedication, have educational scientific research ability, and diligent in teaching and research, with the reform of teaching content teaching methods, the use of modern teaching equipment and teaching methods, and constantly sum up in the teaching improvement for the development of a new discipline is very important.

Strengthen the Construction of Teachers' Ethics. The attitude and way of the teachers in the work will greatly affect the teaching quality and teaching level. Strengthen the education of teachers' occupation moral, mobilize the enthusiasm and initiative of teachers of political theory study and discussion, to carry out ideological and political education, teachers' occupation moral education and legal consciousness education, to establish the education idea, establish the language knowledge, language skills, cultural awareness, emotional attitude, learning strategies and teachers' occupation skill training education teaching is the main content of the concept of routine management, classroom teaching, learning and discussing the teaching arrangements in the business school and the Department of the Ministry of learning activities in the formulation of management procedures, check and implement the work to grasp, to comprehensively strengthen the cultivation of teachers' Professional theory thought, and improve the long-term work for the task.

\section{To Form a Good Teaching Environment}

Teaching environment is a special environment, it has the education system is relatively closed, stable and independent, is a combination of material and social conditions of school personnel to carry out various activities in teaching mainly depends on the good school environment is students' learning activities rely on the material basis and economic conditions. It points out that the environment includes the external environment and internal environment, and the teaching environment also includes the external environment and internal environment. The external environment is the classroom, blackboard, multimedia, desks, chairs and other hardware facilities, and the internal environment is the student's learning atmosphere, teacher-student relationship, psychological environment, style of study, etc..

The teaching of business English major is the process of cultivating the compound talents. The connotation of business English is "discipline construction and development direction of business + skill" as the characteristics of the practical, occupation type; to establish employment oriented, professional skills as the focus, from the actual situation of students, the teaching mode of training; develop team spirit, focus on training objectives, continuous reform and innovation the teaching management and student management. For a long time, China's higher education is the main function of cultivating advanced talents, and is based on the prediction of all walks of life in the social and economic development of specialized personnel to determine the number of admissions for various professional categories, the school for students of professional education in accordance with the professional direction, the basic pattern after graduation to let them according to the professional direction of "employment" as the operation of the university. However, the direction of talents training in Colleges and universities is to serve the society, which is regulated by the market demand, which requires colleges and universities to recognize the situation, change the mode of education and training, and make the best of it as soon as possible. The compound talents of business English are versatile talents, which are characterized by the ability to carry out business activities in the field of international business communication. Colleges and universities to adapt to the market and the trend of social development, the establishment of the professional teaching, to cultivate applied talents for the development of our socialist market economy, the characteristics of the decision for everyone to improve their overall quality, it is necessary to expand the personal knowledge. As a teaching unit, we must adhere to the training mode of business English Subject Construction: English language skills + business and management related technologies. 


\section{Acknowledgements}

This paper is supported by Philosophy and Social Scientific Research Project Foundation of Heilongjiang Province (No.14C009).

\section{References}

[1] Avery.G. C, Leadership for Sustainable Futures Achieving Success in a Competitive World, first ed., Edward Elgar, 2010.

[2] Bacon.C. S, Enhancing Critical Thinking Skills through Conversation in the Classroom, J. Sci. Commun. 11 (2011) 178-179.

[3] Cottrell. S, Critical Thinking Skills: Developing Effective Analysis and Argument, first ed., American Irwin, 2011.

[4] Cowen. T, Creative Destruction: How Globalization is changing the World's Cultures, first ed., Princeton University Press, 2012.

[5] Elsa Dent, The Leadership Pocketbook, first ed., Management Pocketbooks, 2003.

[6] Michalak.S. J, Liberal Education, J.Sci.Commun.156 (2011) 78.

[7] Quilliam. S, Positive Thinking, third ed., United States: DK Publishing, New York, 2008.

[8] Stamm. B. V, Managing, Innovation, Design, and Creativity, third ed., John Wiley \& Sons Ltd, Washington, 2003.

[9] Taylor. W. M, Informal Logic, J.Sci.Commun. 10 (2012) 19-22.

[10] Thompson. J. N, On Being a Successful Graduate Student, first ed., University of California, 2005. 